\title{
Aplikasi Simulasi dan Main Angklung (Saung) Berbasis Android
}

\author{
Danal Meizantaka Daeanza*), Oky Dwi Nurhayati, Dania Eridani \\ Departemen Sistem Komputer, Fakultas Teknik, Universitas Diponegoro \\ Jl. Prof. Soedarto, SH, Kampus Undip Tembalang, Semarang, Indonesia 50275
}

\begin{abstract}
The modern way of thinking cause traditional music instruments start to lose its enthusiasm. Today's generation is more familiar with multimedia features presented by computers. Angklung which is one of the world heritage of musical instruments from Indonesian culture is the one that affected by the rapid technology development. Based on such situation, this research is conducted to design a mobile device application which introduces Angklung. The Application is implemented on a mobile device with Android Operating System. The method used in this research is Multimedia Development Life Cycle (MDLC). The evaluation of this application uses two parameters, the Black-box method, and questionnaire. Black-box method evaluation results showed that this application is running according to specification requirements. The result obtained from the questionnaire with Likert scale showed the average score from each question is $88 \%$. So it can be concluded that the application gains positive feedback and has been qualified to be considered as good.
\end{abstract}

KEYWORDS - Application; Multimedia; Angklung; Android; MDLC; Blackbox; Questionnarire; Likert Scale

Abstrak-Pola pikir yang dipandang modern membuat alat musik tradisional semakin kehilangan penggemar. Generasi muda lebih akrab dengan fitur multimedia yang disuguhkan oleh komputer. Angklung yang merupakan alat musik warisan dunia dari kebudayaan asli Indonesia menjadi salah satu yang terkena dampak dari perkembangan pesat teknologi. Berdasarkan hal tersebut dilakukan penelitian untuk merancang sebuah aplikasi perangkat seluler untuk mengenalkan angklung. Aplikasi ini diimplementasikan pada perangkat seluler dengan sistem operasi Android. Metodologi yang digunakan dalam penelitian ini adalah Multimedia Development Life Cycle (MDLC). Pengujian aplikasi menggunakan dua jenis parameter pengujian yaitu metode black-box dan kuesioner. Metode black-box menunjukkan bahwa aplikasi sudah berjalan sesuai spesifikasi kebutuhan begitu juga dengan tiap fungsi aplikasi. Hasil yang diperoleh dari data kuesioner dengan implementasi skala likert yaitu sebesar 88\%. Dapat disimpulkan bahwa aplikasi yang dibuat mendapat tanggapan positif dan telah memenuhi syarat untuk dianggap baik.

KATA KUNCI : Aplikasi; Multimedia; Angklung; Android; MDLC; Blackbox; Kuesioner; Skala Likert

\footnotetext{
*) Penulis korespodensi (Danal Meizantaka Daeanza) Email: danalmeizantaka@gmail.com
}

\section{PENDAHULUAN}

Angklung merupakan salah satu alat musik kebudayaan asli dari Indonesia. Alat musik ini lebih banyak di kembangkan di daerah Jawa[1]. Angklung adalah alat musik yang terbuat dari pipa-pipa bambu, yang dipotong ujungujungnya, menyerupai pipa-pipa dalam suatu organ, dan diikat bersama dalam suatu bingkai, digetarkan untuk menghasilkan bunyi[2]. Dalam kapasitasnya sebagai alat musik, angklung merupakan satu bentuk alat musik yang terkena sentuhan kreatif. Dalam arti, angklung merupakan satu bentuk alat musik hasil kreativitas individu pembuatnya[3].Pada tahun 2010, UNESCO menetapkan angklung sebagai salah satu warisan budaya takbenda[4]. Berbeda dengan perkembangan teknologi yang sangat cepat, perkembangan nilai dan budaya di Indonesia pun semakin tergerus. Generasi muda yang dianggap penerus kehidupan bangsa justru semakin asing terhadap alat musik tradisional warisan dunia.

Pola pikir yang dipandang modern membuat alat musik tradisional semakin kehilangan penggemar. Dibanding hiburan tradisional, masyarakat era sekarang ternyata lebih akrab dengan fitur multimedia yang ada di perangkat komputer. Fitur multimedia di komputer yang menggabungkan teks, animasi, gambar, suara, video, dan interaktivitas dianggap lebih praktis dan menyenangkan[5]. Hal ini terjadi karena kekayaan elemen - elemen dan kemudahannya untuk digunakan dalam banyak konten yang bervariasi. Saat ini perkembangan multimedia dalam bentuk aplikasi komputer mengalami pertumbuhan pesat sehingga jenisnya pun makin beragam[6]. Dengan penggunaan multimedia, penyampaian informasi akan menjadi lebih menarik dan mempermudah pengguna dalam mendapatkan informasi tersebut. Seseorang hanya akan mendapatkan $20 \%$ dari apa yang mereka lihat dan 30\% dari yang mereka dengar. Sedangkan melalui multimedia akan mendapatkan $50 \%$ dari apa yang mereka lihat dan dengar, sampai $80 \%$ dari apa yang mereka lihat, dengar dan berinteraksi dengan pada waktu yang sama[7].

Penelitian [8] berjudul "Perancangan Aplikasi Pengenal Alat Musik Tradisional "Gandara” Menggunakan MultiPoint Mouse SDK” merupakan aplikasi hasil implementasi ide untuk membuat simulasi gamelan dan angklung yang berbasis desktop dan memanfaatkan fitur MultiPoint Mouse SDK sehingga dapat dimainkan oleh beberapa pengguna secara langsung.

Penelitian ini berfokus pada bagaimana merancang dan membuat aplikasi simulasi dan main angklung (Saung) sebagai media pengenalan kepada masyarakat umum berbasis sistem operasi Android dan menggunakan tools Unity. Android merupakan suatu sistem operasi untuk telepon seluler 
berbasiskan Linux yang menyediakan platform terbuka bagi para pengembang untuk menciptakan aplikasi mereka sendiri sehingga dapat digunakan oleh berbagai macam piranti bergerak[9]. Piranti bergerak digunakan karena mempermudah distribusi aplikasi dan semakin mudah juga dimainkan. Unity adalah sebuah sebuah tool yang terintegrasi untuk membuat game, arsitektur bangunan dan simulasi[10]. Dengan dibuatnya sebuah aplikasi simulasi dan main angklung (Saung) berbasis Android ini harapannya dapat ikut membantu melestarikan serta mengenalkan kembali alat musik angklung dengan konsep multimedia yang menarik terhadap masyarakat umum.

\section{Metode Penelitian}

\section{A. Tahap Pengembangan Multimedia}

Pengembangan multimedia dalam penelitian ini menggunakan metodologi Multimedia Development Life Cycle (MDLC). Metodologi ini terdiri dari enam tahap yang dilakukan meliputi tahap konsep (concept), tahap desain (design), tahap pengumpulan materi (material collecting), tahap pembuatan (assembly), tahap pengujian (testing) dan tahap distribusi (distribution).

\section{B. Konsep}

Aplikasi yang dibuat dalam penelitian ini bertujuan untuk membuat simulasi dan permainan dari salah satu alat musik yaitu angklung serta membantu melestarikan dan mengenalkan kembali alat musik angklung dengan konsep multimedia yang menarik. Obyek penelitian ini memiliki kategori pada jenjang sekolah menengah pertama hingga perguruan tinggi. Aplikasi simulasi dan main angklung ini akan diberi nama "Saung". Nama aplikasi "Saung" merupakan akronim dari simulasi dan main angklung, diberi nama "Saung" agar obyek penelitian dapat mudah mengingat dan mengenalinya.

Sebagai acuan pembuatan aplikasi pada tahap berikutnya maka perlu disusun suatu skenario agar aplikasi yang dibuat sesuai dengan apa yang diharapkan. Skenario dari aplikasi "Saung" ini yaitu sebagai berikut:

1. Aplikasi "Saung" terdiri dari delapan buah halaman utama yaitu splash screen, halaman menu awal, halaman simulasi, halaman not satuan, halaman not banyak, halaman main, halaman info dan halaman pengaturan.

2. Pada splash screen pengguna dapat menyentuh layar untuk masuk ke halaman menu awal.

3. Pada halaman menu awal pengguna dapat memilih menu yang diinginkan seperti menu simulasi, menu main, menu pengaturan dan menu info.

4. Pada menu info terdapat bantuan-bantuan berupa teks yang digunakan untuk mengarahkan dan membantu pengguna mengenai setiap fungsi dari halaman simulasi dan halaman main.

5. Pada menu pengaturan pengguna dapat mematikan suara, mengetahui tentang aplikasi, tentang pembuat dan credit.

6. Pada menu simulasi pengguna dapat memilih dua fitur yang disajikan antara not satuan dan not banyak.

7. Not satuan dipilih pengguna agar pengguna dapat menyimulasikan alat musik angklung dengan memilih salah satu notasi angka dasar yaitu 1 (do), 2 (re), 3 (mi), 4 (fa), 5 (sol), 6 (la), 7 (si) dan 1' (do') serta memainkan not tersebut dengan cara menggoyangkan perangkat seluler ke kanan dan kiri untuk mengeluarkan suara dari not tersebut.
8. Not banyak dipilih pengguna agar pengguna dapat langsung menyimulasikan alat musik angklung dengan semua notasi angka dasar dalam satu antarmuka yang bergambar delapan buah angklung dengan masingmasing notasi angka dasar dan akan mengeluarkan suara sesuai dengan nadanya jika angklung disentuh.

9. Pada menu main pengguna dapat bermain dengan cara memilih salah satu lagu yang disajikan, setelah memilih lagu pengguna akan mulai memainkan permainan dengan cara menyentuh setiap activator yang telah disediakan ketika note turun dan bersentuhan dengan activator. Setiap note yang disentuh tepat dengan activator maka akan tercatat di skor. Setelah permainan selesai maka skor yang didapat akan dibandingkan dengan skor sebelumnya dan ditampilkan pada papan skor terbaik.

\section{Desain}

Dalam tahap desain ini dibagi menjadi dua, yaitu merancang aplikasi dengan menggunakan use case diagram dan sequence diagram serta merancang merancang desain tampilan aplikasi.

\section{Pengumpulan Materi}

Dalam tahap ini dilakukan pengumpulan materi yang diperlukan dalam pembuatan aplikasi, termasuk di dalamnya gambar, suara dan animasi. Gambar digunakan untuk membuat tampilan aplikasi yang menarik, juga untuk menggambarkan alat musik angklung dalam bentuk dua dimensi dan dengan didominasi jenis gaya desain flat. Begitu juga dengan suara yang digunakan untuk menghasilkan bunyi simulasi alat musik angklung agar mirip dengan aslinya. Ditambahkan pula dengan beberapa animasi untuk membuat tampilan aplikasi tampak lebih interaktif.

\section{E. Pembuatan}

Kebutuhan perangkat lunak dan perangkat keras yang digunakan untuk membuat aplikasi ini. Pertama dimulai dari perangkat lunak yang digunakan sebagai berikut :

1. Microsoft Windows 8.1 Professional

Sistem operasi ber-platform windows yang digunakan untuk membuat dan mengembangkan aplikasi ini.

2. Unity 5.3.5f1

Unity adalah sebuah game engine yang berbasis lintas platform.

3. Adobe Illustrator CS 6

Perangkat lunak yang berguna untuk merancang grafis berbasis vektor dua.

4. Corel Draw X7

Perangkat lunak yang berguna untuk merancang grafis berbasis vektor.

5. FruityLoops

Perangkat lunak yang berguna untuk membuat audio pada aplikasi.

Kemudian perangkat keras yang digunakan dalam penelitian ini yaitu sebuah komputer desktop dengan spesifikasi sebagai berikut :

1. Prosesor Intel ® Pentium @ CPU G620 @ 2.60GHz.

2. RAM 4,00 GB.

3. Harddisk 500 GB.

4. Monitor 25 Inchi.

5. Satu buah mouse dan keyboard.

Perangkat keras tambahan yang digunakan untuk aplikasi akan dirancang pada perangkat seluler sistem operasi Android dengan minimal API 19 (KitKat) dan target API 22 (Lollipop). Proses uji coba akan dilakukan pada perangkat 
seluler Xiaomi Redmi Note 3 dengan sistem operasi Android versi Lollipop. berikut :

Adapun spesifikasi dari Xiaomi Redmi Note 3 sebagai

1. CPU Octa-Core $2.0 \mathrm{GHz}$ Cortex-A53.

2. RAM 3 GB.

3. Resolusi 1080 x 1920 pixels.

F. Pengujian

Pengujian aplikasi dilakukan pada tahap ini, apakah aplikasi yang dibuat telah sesuai dengan perancangan dan kebutuhan atau belum. Pengujian nantinya akan dilakukan per menu, bukan setelah semua aplikasi selesai. Dengan menggunakan pengujian per menu akan mempermudah dalam mendeteksi kesalahan karena ketika terdapat kesalahan dari suatu menu maka dapat langsung diperbaiki.

Pengujian yang digunakan dalam pembuatan aplikasi menggunakan metode pengujian Black Box Testing. Setelah tahap pengujian ini selesai dan aplikasi sudah selesai maka dilanjutkan dengan pengujian aplikasi menggunakan kuesioner kepada responden. Pengujian menggunakan kuesioner digunakan untuk mendapatkan saran-saran dari responden guna kelayakan aplikasi ini.

\section{G. Distribusi}

Hasil pembuatan aplikasi ini kemudian akan didistribusikan melalui Google Play Store. Google Play Store dipilih karena mempermudah pendistribusian pada perangkat seluler dan sangat mendukung sistem operasi Android. Selain itu pengguna juga dapat dengan mudah mengunduh nya.

\section{HASIL DAN PEMBAHASAN}

\section{A. Hasil Pembuatan Aplikasi "Saung"}

Pembuatan aplikasi ini diimplementasi berdasarkan perancangan yang telah dibahas pada Bab III, sehingga dihasilkan suatu permainan yang bekerja sesuai dengan fungsinya. Sedangkan pengujiannya dilakukan dengan metode black-box, serta akan dilakukan juga uji coba permainan secara langsung ke pengguna menggunakan kuesioner. Berikut ini merupakan tampilan aplikasi yang telah dibuat. Berdasarkan struktur navigasi yang ditunjukkan pada Gambar 1.

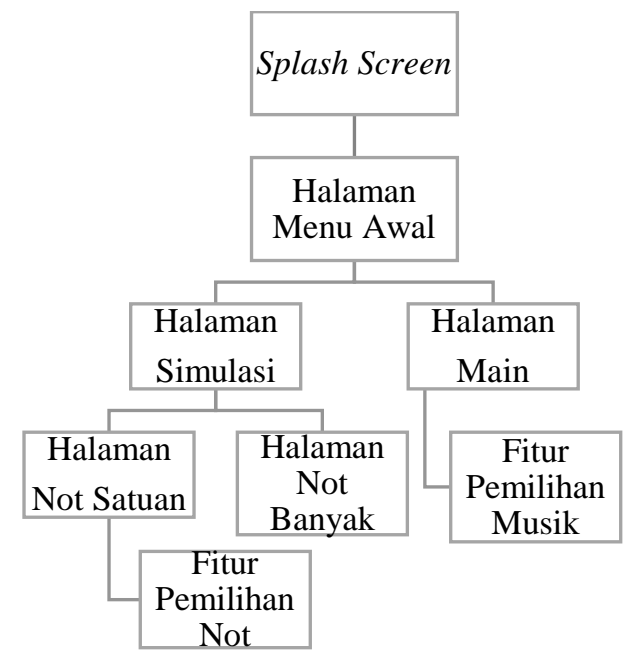

Gambar 1. Struktur Navigasi Aplikasi

1. Antarmuka Splash Screen

Splash screen merupakan halaman pertama yang muncul pada saat aplikasi dijalankan. Pada halaman ini terdapat satu tombol yaitu tombol mulai untuk masuk pada menu utama dari aplikasi. Splash screen juga menyajikan animasi angklung yang bergerak naik turun sebagai penambah daya tarik dari Copyright (C)2017, JTSiskom, e-ISSN:2338-0403 pengguna aplikasi "Saung”. Antarmuka halaman awal aplikasi ditunjukkan pada Gambar 2.

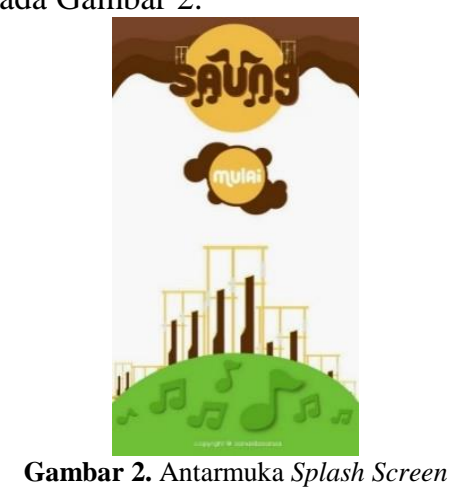

2. Antarmuka Halaman Menu Awal

Halaman menu awal merupakan halaman yang akan muncul ketika pengguna telah melewati halaman awal. Pada halaman menu awal aplikasi ini terdapat empat pilihan tombol yaitu :

a. Tombol Simulasi

b. Tombol Main

c. Tombol Pengaturan

d. Tombol Info

Pada antarmuka halaman menu awal ini juga terdapat logo dan terdapat pula menu pilihan untuk keluar ketika pengguna menekan tombol back pada perangkat seluler. Antarmuka halaman menu awal ditunjukkan pada Gambar 3 dan Gambar 4 dengan menu pilihan untuk keluar.

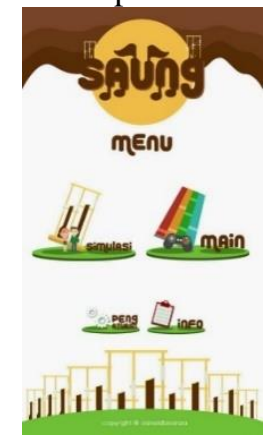

Gambar 3. Antarmuka Halaman Menu Awal

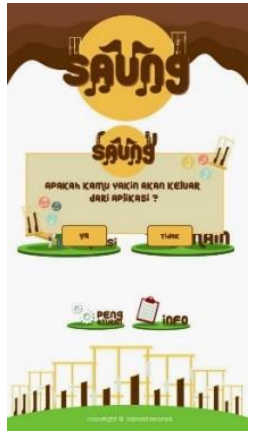

Gambar 4. Antarmuka Halaman Menu Awal dengan Menu Keluar

\section{Antarmuka Halaman Menu Simulasi}

Halaman menu simulasi merupakan halaman yang selanjutnya digunakan untuk menyimulasikan angklung. Apabila tombol simulasi pada halaman menu awal dipilih maka akan menampilkan halaman menu simulasi. Pada halaman menu simulasi terdapat dua tombol yaitu tombol note satuan dan note banyak. Halaman menu simulasi juga dilengkapi dengan tombol back untuk kembali ke halaman sebelumnya yaitu halaman menu awal. Antarmuka halaman menu simulasi ditunjukkan pada Gambar 5. 


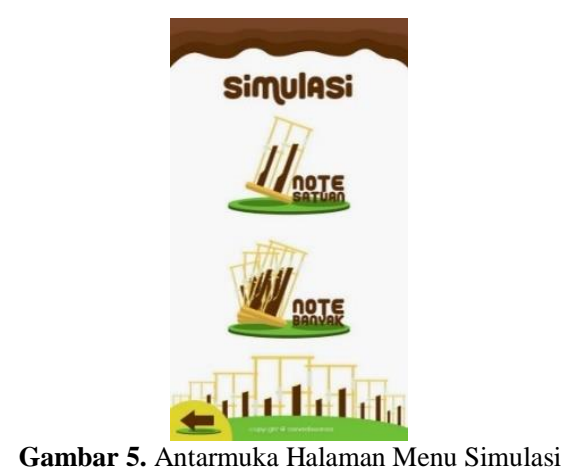

Gambar 5. Antarmuka Halaman Menu Simulasi

Fitur pertama yang dapat dipilih pada halaman menu simulasi adalah note satuan. Pada saat tombol note satuan dipilih maka akan masuk ke antarmuka halaman note satuan. Halaman note satuan akan menyajikan delapan pilihan nada yang dapat dipilih. Memilih salah satu tombol untuk menentukan suara yang akan disimulasikan. Halaman note satuan juga dilengkapi dengan tombol back untuk kembali ke halaman sebelumnya yaitu halaman menu simulasi. Antarmuka halaman note satuan ditunjukkan pada Gambar 6 dan antarmuka halaman simulasi note satuan ditunjukkan pada Gambar 7.

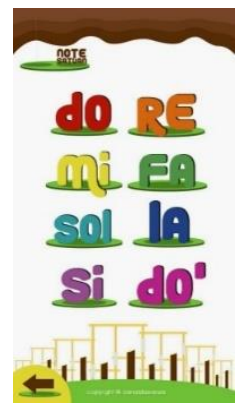

Gambar 6. Antarmuka Halaman Note Satuan

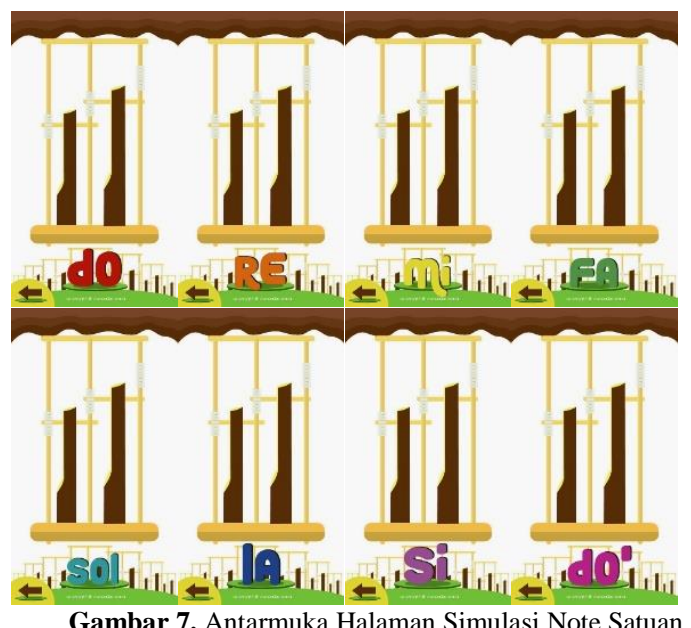

Fitur kedua yang dapat dipilih pada halaman menu simulasi adalah fitur simulasi note banyak. Pada saat tombol note banyak dipilih maka akan masuk ke antarmuka halaman fitur simulasi note banyak. Halaman fitur simulasi note banyak akan menyajikan antarmuka dengan bilah angklung yang disusun sedemikian rupa. Pada halaman fitur simulasi note banyak dibagian bawah angklung terdapat penanda berupa gambar yang bertuliskan nama tangga nada. Jika angklung "do" disentuh maka penanda juga akan berubah warna, menandakan bahwa angklung dengan nada tersebut baru saja disentuh. Hal itu juga berlaku untuk nada yang lainnya, jika bilah angklung yang lain di sentuh maka penanda akan berubah warna. Halaman fitur simulasi note banyak juga dilengkapi dengan tombol back untuk kembali ke halaman sebelumnya yaitu halaman menu simulasi. Antarmuka halaman fitur simulasi note banyak ditunjukkan pada Gambar 8.

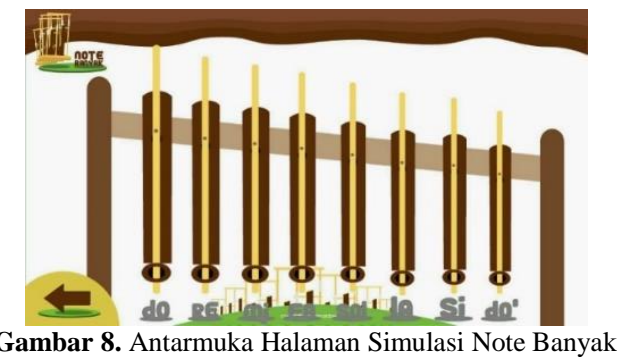

4. Antarmuka Halaman Menu Main

Halaman menu main merupakan halaman yang selanjutnya digunakan untuk bermain permainan sederhana. Apabila tombol main pada halaman menu awal dipilih maka akan menampilkan halaman menu main pilih lagu. Pada halaman menu main pilih lagu terdapat tiga tombol untuk memilih lagu dengan masing - masing tingkat kesulitannya, dimulai dari tombol lagu paling atas dengan tingkat kesulitan paling sulit dan semakin ke bawah semakin mudah yaitu lagu Canon Rock, Bendera dan Manuk Dadali. Halaman menu main pilih lagu juga dilengkapi dengan tombol back untuk kembali ke halaman sebelumnya yaitu halaman menu awal. Antarmuka halaman menu main pilih lagu ditunjukkan pada Gambar 9.

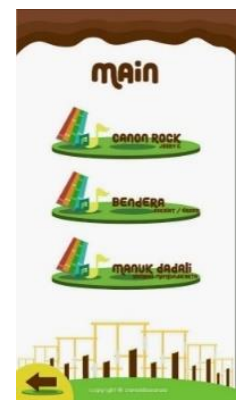

Gambar 9. Antarmuka Halaman Menu Main Pilih Lagu

Setelah salah satu tombol lagu dipilih maka antarmuka halaman baru akan muncul yaitu halaman mulai main. Pada halaman mulai main pengguna akan mengenal antarmuka baru yang dapat digunakan untuk bermain seperti activator, note, parameter dan skor. Cara memainkannya cukup mudah ketika lagu mulai bermain pengguna cukup menekan activator ketika note mulai menyentuh bagian activator untuk mendapatkan skor dan parameter akan ikut bertambah juga, jika pengguna menekan activator sebelum note menyentuh activator atau note berhasil melewati activator dan tidak berhasil ditekan oleh pengguna maka parameter akan berkurang. Antarmuka halaman mulai main ditunjukkan pada Gambar 10.

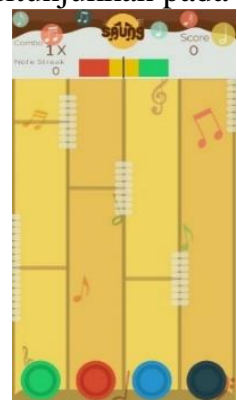

Gambar 10. Antarmuka Halaman Mulai Main

\section{B. Pengujian Aplikasi dengan Metode Black-box}

Pengujian aplikasi "Saung" yang telah dibuat dalam penelitian ini dilakukan dengan menggunakan metode blackbox. Tahapan pengujian ini berisi rangkaian pengujian tombol

Jurnal Teknologi dan Sistem Komputer, 5(1), 2017, 40 
dan fungsi yang terdapat dalam aplikasi. Pengujian dijalankan pada perangkat seluler Xiaomi Redmi Note 3.

Pengujian ini dilakukan untuk memeriksa fungsi yang terdapat dalam aplikasi, apakah hasilnya sesuai dengan yang diinginkan. Pengujian ini juga dilakukan untuk mengetahui apakah masih terdapat kesalahan dalam aplikasi ataukah masih terdapat kesalahan sehingga secepatnya dapat diberi solusi.

Sebagai contoh pada Tabel 1 ditunjukkan contoh pengujian aplikasi menggunakan metode black-box tentang fungsi umum aplikasi.

Tabel 1. Tabel Pengujian Aplikasi Secara Keseluruhan

\begin{tabular}{|c|c|c|c|}
\hline $\begin{array}{c}\text { Nama } \\
\text { Pengujian }\end{array}$ & $\begin{array}{c}\text { Bentuk } \\
\text { Pengujian }\end{array}$ & $\begin{array}{c}\text { Hasil yang } \\
\text { Diharapkan }\end{array}$ & $\begin{array}{c}\text { Hasil } \\
\text { Pengujian }\end{array}$ \\
\hline $\begin{array}{l}\text { Pengujian } \\
\text { buka } \\
\text { aplikasi }\end{array}$ & $\begin{array}{l}\text { Membuka } \\
\text { aplikasi } \\
\text { "Saung" }\end{array}$ & $\begin{array}{l}\text { Tampil } \\
\text { antarmuka } \\
\text { splash screen, } \\
\text { animasi } \\
\text { angklung } \\
\text { berjalan dan } \\
\text { musik latar } \\
\text { berbunyi }\end{array}$ & Berhasil \\
\hline $\begin{array}{l}\text { Pengujian } \\
\text { tombol } \\
\text { Simulasi }\end{array}$ & $\begin{array}{l}\text { Menekan } \\
\text { tombol } \\
\text { Simulasi }\end{array}$ & $\begin{array}{l}\text { Animasi } \\
\text { tombol } \\
\text { simulasi } \\
\text { berjalan dan } \\
\text { tampil } \\
\text { antarmuka } \\
\text { halaman menu } \\
\text { simulasi }\end{array}$ & Berhasil \\
\hline $\begin{array}{l}\text { Pengujian } \\
\text { tombol Main }\end{array}$ & $\begin{array}{l}\text { Menekan } \\
\text { tombol Main }\end{array}$ & $\begin{array}{l}\text { Animasi } \\
\text { tombol main } \\
\text { berjalan dan } \\
\text { tampil } \\
\text { antarmuka } \\
\text { halaman menu } \\
\text { main pilih } \\
\text { lagu }\end{array}$ & Berhasil \\
\hline $\begin{array}{l}\text { Pengujian } \\
\text { tombol } \\
\text { Pengaturan }\end{array}$ & $\begin{array}{l}\text { Menekan } \\
\text { tombol } \\
\text { Pengaturan }\end{array}$ & $\begin{array}{l}\text { Animasi } \\
\text { tombol } \\
\text { pengaturan } \\
\text { berjalan dan } \\
\text { tampil } \\
\text { antarmuka } \\
\text { halaman menu } \\
\text { pengaturan }\end{array}$ & Berhasil \\
\hline $\begin{array}{l}\text { Pengujian } \\
\text { tombol Info }\end{array}$ & $\begin{array}{l}\text { Menekan } \\
\text { tombol Info }\end{array}$ & $\begin{array}{l}\text { Animasi } \\
\text { tombol info } \\
\text { berjalan dan } \\
\text { tampil } \\
\text { antarmuka } \\
\text { halaman menu } \\
\text { info }\end{array}$ & Berhasil \\
\hline $\begin{array}{l}\text { Pengujian } \\
\text { tombol Note } \\
\text { Satuan }\end{array}$ & $\begin{array}{l}\text { Menekan } \\
\text { tombol Note } \\
\text { Satuan }\end{array}$ & $\begin{array}{l}\text { Animasi } \\
\text { tombol note } \\
\text { satuan } \\
\text { berjalan dan } \\
\text { tampil } \\
\text { antarmuka } \\
\text { halaman note } \\
\text { satuan }\end{array}$ & Berhasil \\
\hline
\end{tabular}

Tabel 1. Tabel Pengujian Aplikasi Secara Keseluruhan (Lanjutan)

\begin{tabular}{|c|c|c|c|}
\hline $\begin{array}{l}\text { Pengujian } \\
\text { tombol Note } \\
\text { Banyak }\end{array}$ & $\begin{array}{l}\text { Menekan } \\
\text { tombol Note } \\
\text { Banyak }\end{array}$ & $\begin{array}{l}\text { Animasi } \\
\text { tombol note } \\
\text { banyak } \\
\text { berjalan dan } \\
\text { tampil } \\
\text { antarmuka } \\
\text { halaman note } \\
\text { banyak }\end{array}$ & Berhasil \\
\hline \multirow[t]{2}{*}{$\begin{array}{l}\text { Pengujian } \\
\text { tombol Do }\end{array}$} & $\begin{array}{l}\text { Menekan } \\
\text { tombol Do }\end{array}$ & $\begin{array}{l}\text { Tampil } \\
\text { antarmuka } \\
\text { halaman } \\
\text { simulasi note } \\
\text { satuan "Do" }\end{array}$ & Berhasil \\
\hline & $\begin{array}{l}\text { Menggoyang } \\
\text { kan } \\
\text { perangkat } \\
\text { seluler ke } \\
\text { kanan atau } \\
\text { ke kiri }\end{array}$ & $\begin{array}{l}\text { Suara "Do" } \\
\text { berbunyi }\end{array}$ & Berhasil \\
\hline $\begin{array}{l}\text { Pengujian } \\
\text { bilah } \\
\text { angklung Do }\end{array}$ & $\begin{array}{l}\text { Menekan } \\
\text { bilah } \\
\text { angklung Do }\end{array}$ & $\begin{array}{l}\text { Suara "Do" } \\
\text { berbunyi dan } \\
\text { penanda "Do" } \\
\text { berubah warna }\end{array}$ & Berhasil \\
\hline $\begin{array}{l}\text { Pengujian } \\
\text { Mulai Main }\end{array}$ & $\begin{array}{l}\text { Menekan } \\
\text { tombol salah } \\
\text { satu lagu } \\
\text { yang ada di } \\
\text { halaman } \\
\text { menu main } \\
\text { pilih lagu }\end{array}$ & $\begin{array}{l}\text { Tampil } \\
\text { antarmuka } \\
\text { halaman mulai } \\
\text { main dan lagu } \\
\text { yang dipilih } \\
\text { bunyi. }\end{array}$ & Berhasil \\
\hline $\begin{array}{l}\text { Pengujian } \\
\text { tombol Back }\end{array}$ & $\begin{array}{l}\text { Menekan } \\
\text { tombol Back }\end{array}$ & $\begin{array}{l}\text { Tampil } \\
\text { halaman menu } \\
\text { simulasi }\end{array}$ & Berhasil \\
\hline \multirow[t]{3}{*}{$\begin{array}{l}\text { Pengujian } \\
\text { Menu } \\
\text { Keluar }\end{array}$} & $\begin{array}{l}\text { Menekan } \\
\text { tombol back } \\
\text { pada } \\
\text { perangkat } \\
\text { seluler }\end{array}$ & $\begin{array}{l}\text { Tampil kotak } \\
\text { dialog Menu } \\
\text { Keluar }\end{array}$ & Berhasil \\
\hline & $\begin{array}{l}\text { Menekan } \\
\text { tombol Ya } \\
\text { pada aplikasi }\end{array}$ & $\begin{array}{l}\text { Aplikasi } \\
\text { tertutup/keluar }\end{array}$ & Berhasil \\
\hline & $\begin{array}{l}\text { Menekan } \\
\text { tombol } \\
\text { Tidak pada } \\
\text { aplikasi }\end{array}$ & $\begin{array}{l}\text { Penutupan } \\
\text { aplikasi } \\
\text { dibatalkan dan } \\
\text { Menu Keluar } \\
\text { hilang }\end{array}$ & Berhasil \\
\hline
\end{tabular}

\section{Pengujian Aplikasi dengan Metode Kuesioner}

Pengujian aplikasi juga dilakukan secara langsung kepada sasaran aplikasi, yaitu pelajar dari jenjang sekolah menengah pertama hingga universitas. Pengujian dilakukan secara obyektif dengan tujuan mengetahui penilaian terhadap aplikasi yang telah dibuat. Proses pengujian ini dilakukan dengan cara meminta sasaran menggunakan aplikasi "Saung" kemudian dilanjutkan memberi kuesioner mengenai beberapa aspek.

Setiap responden akan diberi 9 sampel pertanyaan dimana setiap pertanyaan terdapat 5 pilihan jawaban, yaitu Sangat Tidak Setuju (STS), Tidak Setuju (TS), Netral (N), Setuju (S), Sangat Setuju (SS). Masing-masing jawaban diberi skor berurutan sampai 5 .

Hasil dari pengujian ini didapat nilai yang ditunjukkan diagram batang yang dapat dilihat pada oleh Gambar 11 . 


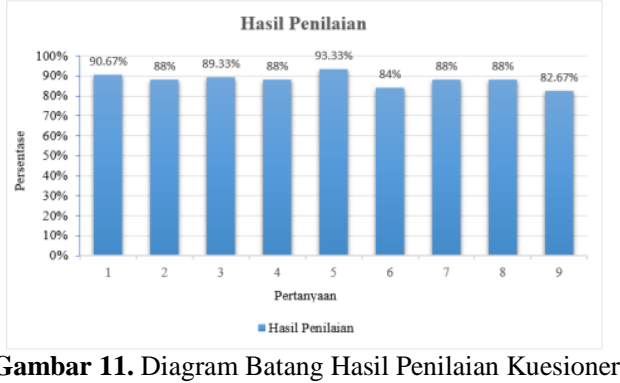

D. Pembahasan

Hasil pengujian aplikasi menggunakan metode blackbox, menunjukkan bahwa permainan secara garis besar sudah berjalan sesuai dengan spesifikasi kebutuhan dan skenario aplikasi. Hal ini ditunjukkan oleh Tabel 1 pada tiap fungsi aplikasi dan tombol. Secara fungsional aplikasi ini sudah dapat menghasilkan keluaran sesuai dengan yang diharapkan.

Seperti dalam batasan masalah, bahwa aplikasi "Saung" ini akan dijalankan pada sistem operasi Android. Setelah dilakukan pengujian, skenario aplikasi ini berjalan dengan baik dan lancar pada perangkat seluler Xiaomi Redmi Note 3. Berdasarkan pengujian yang telah dilakukan untuk mendistribusikan aplikasi pada beberapa perangkat seluler lainnya terdapat perbedaan kinerja. Perbedaan kinerja tersebut terdapat pada saat menggunakan fitur main pada lagu Canon Rock. Perangkat seluler yang digunakan untuk pendistribusian yaitu Xiaomi Redmi Note 3 dengan versi Android 5.1.1 Lollipop (API 22), Lenovo A6000 dengan versi Android 4.4.4 Kitkat (API 19) dan Lenovo A7000 Plus dengan versi Android 6.0 Marshmallow (API 23). Ketiga perangkat seluler tersebut telah berhasil dalam distribusi dan implementasi aplikasi secara keseluruhan, namun pada fitur main yaitu lagu Canon Rock terdapat perbedaan saat permainan dimulai. Perangkat seluler Xiaomi Redmi Note 3 mengimplementasikan lagu Canon Rock dengan sangat lancar, Lenovo A7000 Plus mengimplementasikan lagu Canon Rock dengan cukup lancar dan Lenovo A6000 mengimplementasikan lagu Canon Rock dengan kurang lancar.

Berdasarkan rumus rata-rata (mean) didapat skor ratarata dari semua pertanyaan yaitu sebesar $88 \%$. Pada rumus skala likert, untuk mendapatkan nilai sebesar $100 \%$ dibutuhkan 15 responden dengan jawaban "Sangat Setuju" pada kesembilan pertanyaan dalam kuesioner untuk dianggap bahwa aplikasi sangat disetujui sebagai sarana pengenalan alat musik angklung atau sudah sangat baik. Untuk mendapatkan syarat dianggap bahwa aplikasi disetujui sebagai sarana pengenalan alat musik angklung atau baik maka diperlukan setidaknya $80 \%$ atau dari 15 responden menjawab dengan jawaban "Setuju" pada kesembilan pertanyaan dalam kuesioner. Sesuai dengan analisis tentang persentase dari kuesioner di atas maka dapat disimpulkan bahwa aplikasi yang dibuat dengan persentase sebesar $88 \%$ sesuai Tabel 4.20 dan rumus rata-rata (mean) telah memenuhi syarat untuk dianggap baik karena memiliki hasil nilai lebih dari $80 \%$.

E. Distribusi

Setelah melewati tahap pengujian, tahap terakhir dalam pengembangan MDLC adalah tahap distribusi. Tahap distribusi merupakan tahap dimana aplikasi permainan sudah bisa disebarluaskan ke pengguna perangkat seluler Android. Langkah pertama yang harus dilakukan adalah melakukan ekspor aplikasi sehingga membentuk ekstensi apk agar bisa digunakana pada perangkat seluler Android. Dalam tahap ini aplikasi permainan ini telah didistribusikan ke Google Play Store.

Permainan ini sudah dapat diunduh dari Google Play Store dengan nama aplikasi "Simulasi \& Main Angklung" atau bisa diunduh melalui alamat https://play.google.com/store/apps/details?id=com.DanalMe izantakaDaeanza.Saung\&hl=in. Tampilan aplikasi "Saung" di Google Play Store ditunjukkan pada Gambar 12.

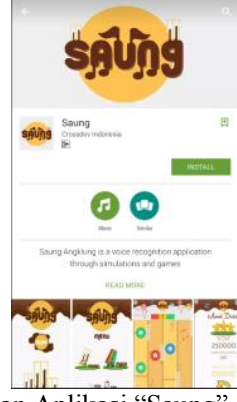

Gambar 12. Tampilan Aplikasi "Saung" di Google Play Store

\section{KESIMPULAN}

Berdasarkan hasil pengujian yang telah dilakukan didapatkan hasil bahwa aplikasi simulasi dan main angklung (Saung) telah berhasil dirancang menggunakan Unity dan dapat berjalan lancar pada perangkat seluler Xiaomi Redmi Note 3 yang memiliki sistem operasi Android 5.1.1 Lollipop (API 22). Berdasarkan hasil pengujian aplikasi menggunakan metode Black-box, seluruh fungsi menu yang ada dalam aplikasi telah berhasil sesuai dengan fungsinya. Sedangkan hasil pengujian aplikasi "Saung" menggunakan olahan data kuesioner menunjukkan bahwa $88 \%$ lebih responden menjawab dengan jawaban positif atau dapat dikatakan aplikasi ini sudah berhasil dengan baik dengan mengimplementasikan nilai multimedia

\section{DAFTAR PUSTAKA}

[1] M. A. Kamarullah, "Perancangan Kampanye Meningkatkan Apresiasi Terhadap Angklung Sebagai Budaya Indonesia Bagi Remaja," Jurnal Tingkat Sarjana bidang Senirupa dan Desain ITB, vol. I, 2012.

[2] J. Rigg, Dictionary of the Sunda Language, Batavia: Lange \& co, 1862.

[3] D. Hermawan, Angklung Sunda Sebagai Wahana Industri Kreatif dan Pembentukan Karakter Bangsa, Bandung: Jurnal Seni \& Budaya Panggung, STSI, 2013.

[4] A. Pratiwi, Pelestarian Angklung Sebagai Warisan Budaya Takbenda dalam Pariwisata Berkelanjutan di Saung Angklung Udjo Bandung, Denpasar: Tesis-S2, Universitas Udayana, 2013.

[5] A. H. Sutopo, Multimedia Interaktif Dengan Flash, Jakarta: Graha Ilmu, 2010.

[6] T. Vaughan, Multimedia: Making It Work, 5th Edition, Osborne, 2011.

[7] F. T. Hofstetter, Multimedia Literacy, 3rd Edition, Irwin/MCGraw-Hill, 2011.

[8] A.B.C. Permana, K.I. Satoto, and K.T. Martono, "Perancangan Aplikasi Pengenal Alat Musik Tradisional Gandara Menggunakan Multipoint Mouse SDK." Jurnal Teknologi dan Sistem Komputer 2, no. 4, pp 223-230, 2014

[9] S. H. S, Mudah Membuat Aplikasi Android, Yogyakarta: Andi, 2011.

[10] R. Rickman, Unity Tutorial Game Engine., Bandung : Informatika Bandung, 2014. 